Apidologie, 1980, 11 (1), 29-38.

\title{
CHARACTERIZATION OF POSTEMBRYONIC DEVELOPMENTAL STAGES OF THE FEMALE CASTES OF THE HONEY BEE, APIS MELLIFERA L.
}

\author{
Heinz REMBOLD, Jean-Pierre KREMER* \\ and Gabriele M. ULRICH \\ Max-Planck-Institut für Biochemie, D-8033 Martinsried
}

\section{SUMMARY}

Queens and workers of the honey bee, Apis mellifera, have been reared as larvae and pupae under defined conditions, and the developmental stages have been associated with unequivocal features. The larval instars are characterized by the head diameter and weight of the larvae. The stages of pupal development are defined by the colours shown by the compound eyes and the thorax. The temporal duration of the successive developmental stages has also been determined. With these criteria a larva or a pupa can be assigned to a definite position on the developmental time axis.

\section{INTRODUCTION}

The formation by Apis mellifera of female castes from larvae with the same genotype offers a fascinating model for studies on differentiation. During a comparatively short space of growth and metamorphosis, the originally bipotent female larva develops into either a queen or a worker. The direction of development is determined during the first $31 / 2$ days of larval life by external factors such as nutrition (ZANDER and BeCKer, 1925; WeAVER, 1957; Rembold and HaNSER, 1964). The resulting differences in size, function, behaviour, morphology and metabolism have been investigated by Stabe (1930), Melampy and Willis (1939), MySER (1954), Jay (1963), OsANAI and Rembold (1968).

Such comparative studies with the castes of honey bee larvae and pupae require an exact determination of the developmental stages. Several authors have described the growth rates of honey bee larvae (STABE, 1930; WANG, 1965). Previous studies from

* In part from a doctoral work to be submitted by J. P. Kremer to University of München, 1980. 
this laboratory used age and position of the larvae in their cells for characterization (Czoppelt and Rembold, 1970; Osanai and Rembold, 1970). A more precise staging of the larva is required sometimes, particularly for investigation of morphological, physiological and biochemical aspects of honey bee differentiation.

The present study describes a simple method of determining the developmental stage of a worker or a queen larva and pupa by head diameter, body weight and pigmentation. These criteria are then used to measure the duration of the different stages.

\section{MATERIALS AND METHODS}

The larvae and pupae used were collected from Apis mellifera carnica colonies held near the institute or near Saulgrub (Bavaria). The correlation of head diameter and body weight was established with worker larvae and pupae from strong field hives. Queens were reared by general methods as described by ZANDER and BECKER (1925) and WeIss (1971); the larvae selected for this purpose (0-24 hours old, weight 0.1-0.3 mg) were grafted into cell cups placed in queenless nurse hives. Head diameter and body weight of 501 worker and 464 queen larvae with a distribution all over the weight range were measured.

Duration of the different larval instars was determined as follows. The queen of a breeding colony was restricted to one comb for 4-6 hours. After 3 days, only the larvae emerged within an interval of 4 hours were retained for further rearing. Worker larvae were left in the breeding colony and the prospective queens were grafted as mentioned above. Head diameters and body weights of queen and worker larvae collected at different times after hatching were determined. Disturbing the larvae too often during an experiment was avoided by rearing 9 distinct series, each with a different collecting interval, to give differences in age of 4-6 hours between the larval groups.

The pigmentation and duration of the different pupal stages of queens and workers was studied with animals that grew up undi-sturbed in the colonies until their cells were sealed or until pupation. The tops of the cells were then first opened far enough to allow observation of the compound eyes and the thorax, and then closed with a coverslide. The cells were kept in an incubator at 34 " $\mathrm{C}$ with a relative humidity of $70-80 \%$ and were examined every 6 hours until adult ecdysis occured. Final analysis was performed with 370 data from 22 queens, and 1860 data from 55 workers. Eye pigmentation was estimated according to the colour chart RAL-F 2 (RAL, 1976).

\section{RESULTS}

\section{Characterization of larval and pupal stages}

In 1890 DyAR showed that head width in larval lepidoptera is nearly constant during a defined larval stage, and increases according to a regular geometric progression with the successive ecdyses of a larva. This observation was confirmed for the honey bee by BERTHOLF (1925) and his developmental data have been used by a number of research groups, but statistical data concerning the material as examined by BERTHOLF were not published.

We have compared the head diameters and weights of 501 worker and 464 queen larvae. The resulting correlations (Fig. 1) demonstrate the existence of five groups of 


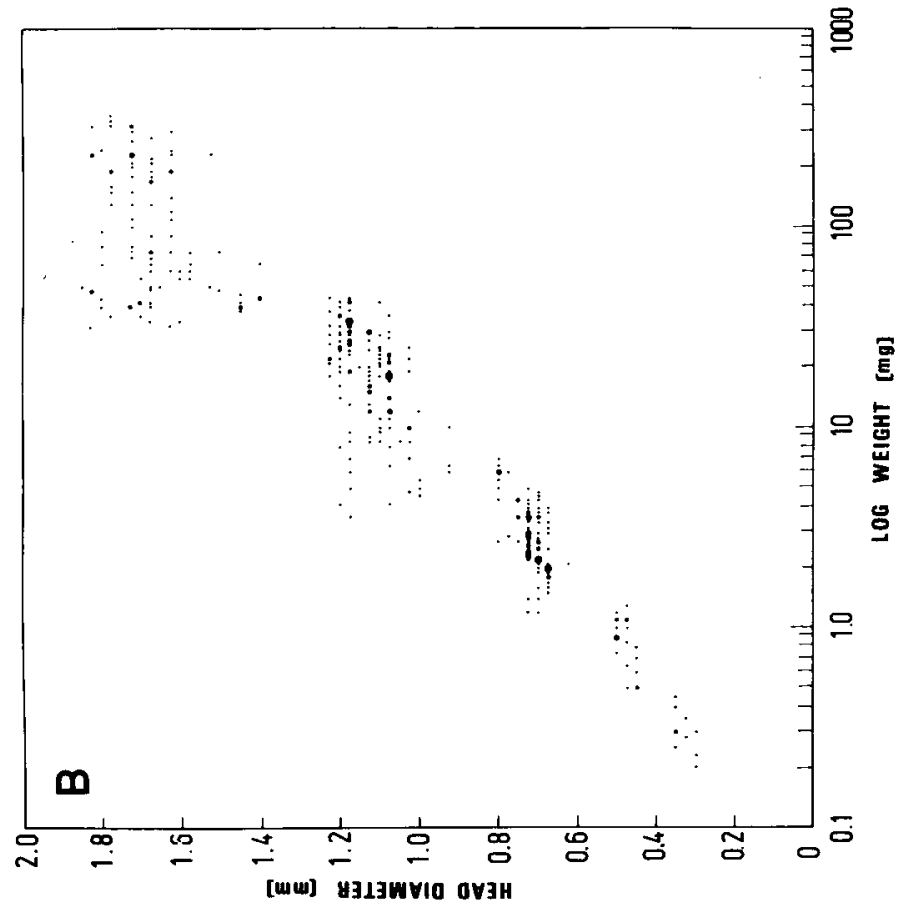

$\underset{0}{2}$

3
5

3

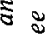

के

एँ

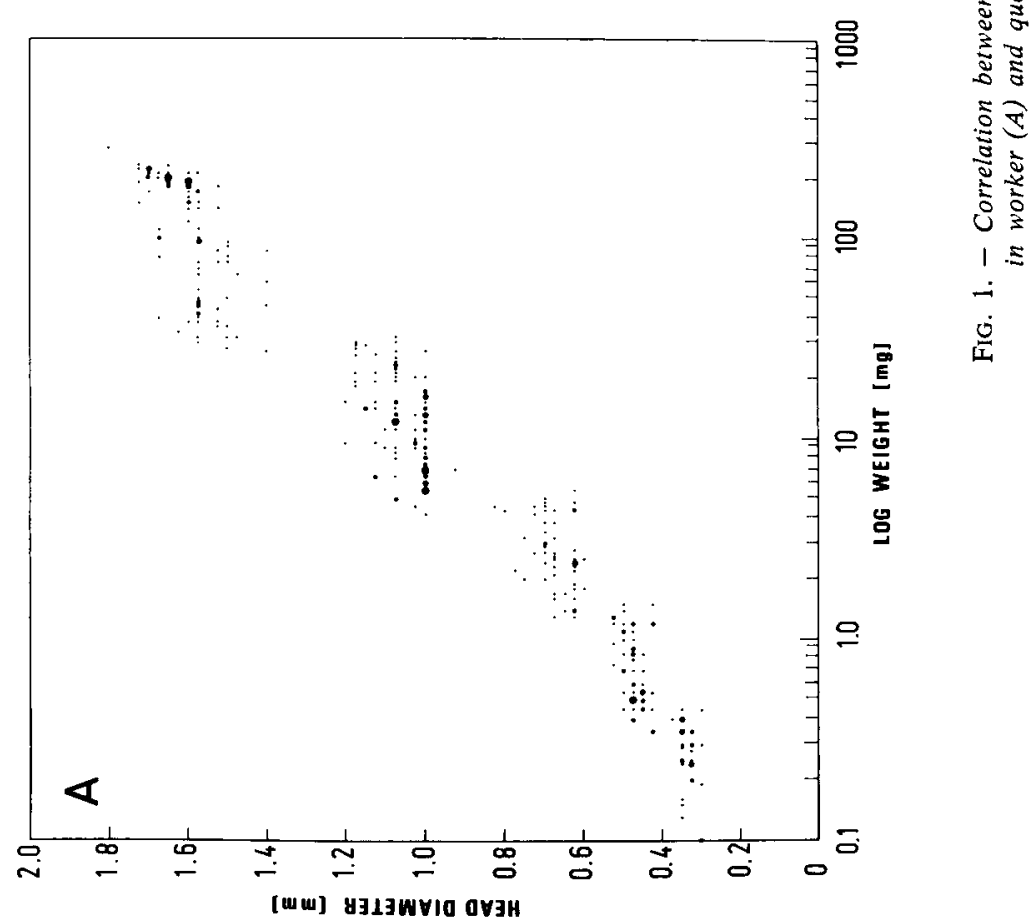


paired data for both queen and worker larvae. A comparison of the average head diameters reveals a highly significant difference between the corresponding groups $(2 \mathrm{p}<0.001)$. This clearly demonstrates that head diameter can be used to characterize each of the 5 larval instars. The average head diameter and corresponding minimum and maximum weights for each larval instar are given in Table 1.

TABL. 1. - Average head diameter and body weight range ${ }^{a}$ of worker and queen larval instars

\begin{tabular}{l|lrcc}
\hline \hline \multirow{3}{*}{ Worker } & $\begin{array}{l}\text { Larval } \\
\text { instar }\end{array}$ & $\mathrm{n}$ & $\begin{array}{c}\text { Head diameter } \\
(\mathrm{mm} \pm \mathrm{SD})^{\mathrm{b}}\end{array}$ & $\begin{array}{c}\text { Larval weight (mg) } \\
\text { min.-max. }\end{array}$ \\
& L 1 & 33 & $0.33 \pm 0.018$ & $0.10-0.45$ \\
& L 2 & 75 & $0.47 \pm 0.030$ & $0.35-1.50$ \\
& L 3 & 101 & $0.70 \pm 0.051$ & $1.3-6.0$ \\
& L 4 & 147 & $1.05 \pm 0.058$ & $4.2-32$ \\
& L 5 + LS & 145 & $1.58 \pm 0.078$ & $27-280$ \\
& Queen & 10 & $0.33 \pm 0.020$ & $0.10-0.45$ \\
& L 2 & 20 & $0.48 \pm 0.026$ & $0.35-1.50$ \\
& L 3 & 113 & $0.72 \pm 0.044$ & $1.3-7.0$ \\
& L 4 & 165 & $1.11 \pm 0.072$ & $3.8-44$ \\
& L 5 LS & 156 & $1.69 \pm 0.097$ & $31-360$ \\
\hline \hline
\end{tabular}

${ }^{a}$ The larval instars are symbolized as follows : L $1-$ L $4=1$ st -4 th larval instar; $L 5=5$ th larval instar before sealing; LS $=5$ th larval instar after sealing.

${ }^{\mathrm{b}} \mathrm{SD}=$ standard deviation.

The fifth larval instar is longer than the preceding ones (see Fig. 2) and can be subdivided into an open-cell phase (L 5) and a spinning phase after the sealing of the cell (LS). According to our observations, a worker cell is sealed at a larval weight of $150-165 \mathrm{mg}$ and a queen cell at a weight of about $190 \mathrm{mg}$.

After spinning, but without ecdysis, the larvae enter the prepupal stage (PP), during which they appear straightened and motionless in their cells, while the larval cuticle progressively loosens from the pupal one underneath, beginning in the head region. This stage ends with the pupal ecdysis.

Pupal development was followed by noting the pigmentation of the compound eyes and the thorax (Tab. 2). The observed colour stages of the eyes were coordinated with the chromaticity values of the RAL-colour chart (RAL, 1976), and divided into larger groups (pink, red brown, dark brown) for easier application. 
TABL. 2. - Characterization of developmental phases in worker and queen pupae ${ }^{a}$

\begin{tabular}{l|c|c}
\hline \multicolumn{1}{c|}{$\begin{array}{c}\text { Pigmentation } \\
\text { of compound eye }\end{array}$} & $\begin{array}{c}\text { Pigmentation } \\
\text { of thorax }\end{array}$ & Symbol \\
\hline white & - & $\mathrm{Pw}$ \\
pink & - & $\mathrm{Pp}$ \\
red brown & - & $\mathrm{Pr}$ \\
dark brown & - & $\mathrm{Pd}$ \\
dark brown & light & $\mathrm{Pdl}$ \\
dark brown & medium & $\mathrm{Pdm}$ \\
dark brown & dark & $\mathrm{Pdd}$ \\
\hline \hline
\end{tabular}

a Eye pigmentation was estimated according to colour chart RAL F 2 (RA1. 1976) : RA1. 3012 pink; RNL 8003. 8004 and 8012 - red brown; RAL 8015,8016 and 8017 - dark brown.

\section{Duration of larval and pupal stages}

Queens and workers, characterized as described above, were used to calculate the duration of the different developmental stages.

Although carefully dated, the larvae did not all grow at the same rate, so a minimum and a maximum duration is given for each larval instar. The temporal durations indicated for pupal development correspond to time intervals comprising $75 \%$ of the observations within each colour group (Tab. 3 and Fig. 2).

\section{DISCUSSION}

Analysis of caste differentiation during the postembryonic development of Apis mellifera and investigation of the related problems of morphology, histology and metabolism require an exact characterization of the animals studied. In the present study we have established simple external criteria that permit a classification of female larvae and pupae in the successive developmental stages.

Different starting points have been proposed for this purpose. STABE (1930) and WANG (1965) correlated the weight and age of larvae, but external factors such as temperature (MıLum, 1930), humidity, food quality and quantity, etc., obviously influence the duration of developmental phases, so age is not a reliable basis for characterizing larvae reared under different conditions and it would probably be still less good if the larvae were of different races. A ninety hours old larva, for example, may be in either the fourth or the fifth larval instar (see Fig. 2).

The instar, on the other hand, is a fundamental step in larval development. Bertholf (1925) used the head size of larvae to determine stage and ecdysis and the 
TABL. 3. - Duration of larval and pupal stages in worker and queen ${ }^{a}$

\begin{tabular}{l|c|c|c|c}
\hline \hline & Worker & & Queen & \\
\cline { 2 - 5 } Stage & $\begin{array}{c}\text { Duration } \\
\text { (hr) }\end{array}$ & $\mathrm{n}$ & $\begin{array}{c}\text { Duration } \\
\text { (hr) }\end{array}$ & $\mathrm{n}$ \\
\hline L 1 & $14-20$ & 20 & $14-20$ & 9 \\
L 2 & $16-22$ & 16 & $16-22$ & 14 \\
L 3 & $18-24$ & 34 & $18-24$ & 27 \\
L 4 & $24-32$ & 25 & $24-32$ & 23 \\
L 5 & $24-36$ & 48 & $24-36$ & 30 \\
LS & $36-54$ & 37 & $30-42$ & 41 \\
PP & $48-60$ & 15 & $30-36$ & 4 \\
Pw & $30-42$ & 34 & $30-36$ & 2 \\
Pp & $18-30$ & 40 & $18-30$ & 11 \\
Pr & $6-18$ & 54 & $6-12$ & 11 \\
Pd & $36-48$ & 53 & $18-30$ & 11 \\
Pdl & $12-24$ & 53 & $6-18$ & 11 \\
Pdm & $30-42$ & 53 & $12-24$ & 8 \\
Pdd & $6-18$ & 45 & $6-12$ & \\
\hline \hline
\end{tabular}

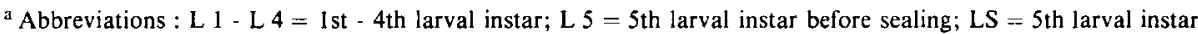
after sealing; $P P=$ prepupa; $P=$ pupa $(w=$ white eyes; $p=$ pink eyes; $d=$ dark brown eyes; $d l=$ dark brown eyes, light pigmented thorax; $\mathrm{dm}=$ dark brown eyes, medium coloured thorax; $\mathrm{dd}=\mathrm{dark}$ brown eyes, dark thorax).

same procedure was applied by WEAvER (1974). Our data on head diameter (Tab. 1) are in substantial agreement with the findings of BERTHOLF. Figure 1 and Table 1, which correlate larval head diameter and weight, allow a larva collected at random from a comb to be assigned to a defined position on the development axis. For routine characterization of larval instars we have used "ecdysis " rather than "apolysis" (apolysis = detachment of the epidermis from the old cuticle; JENKIN and HiNTon, 1966). Apolysis usually can not be observed without histological investigation, except in the prepupa.

The different stages of pupal development are described in term of the pigmentation of compound eyes and thorax (Tab.2). Several authors have described the pigmentation of the honey bee, e.g. StRaus (1911), ZaNDER, Löschel and MEIER (1916), v. RHEIN (1933), JAY (1962). As judgment of colour gradations is well known to be subjective, we have tried to objectify our observations of Apis mellifera carnica pupae by using a colour chart, as THOMPSON (1978) did for $A$. mellifera adansonii.

A further characterization of the postembryonic development is obtained by determining the duration of the different stages in larvae and pupae (Tab. 3). Corresponding descriptions from KoemLer (1923), Bertholf (1925) and WEAVER (1974), e.g., show partially differing results when compared with each other and with our own data. This is not surprising since, as indicated by the overlapping of 


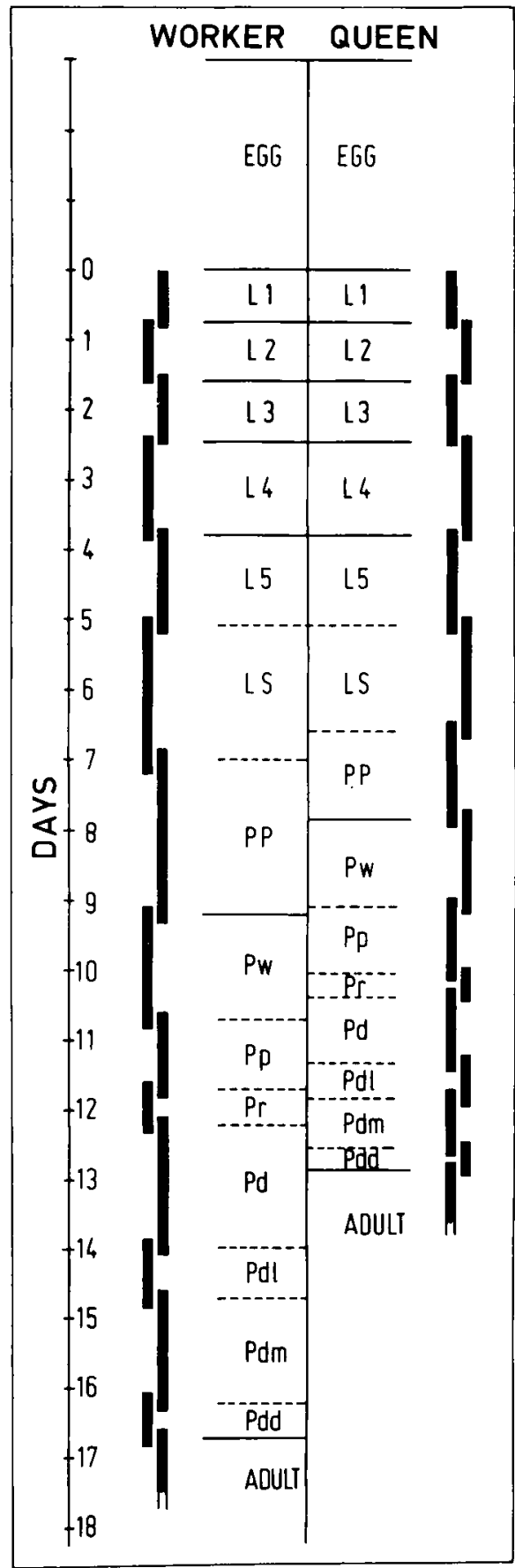

FIG. 2. - Duration of larval and pupal stages in worker and queen honey bees. The vertical bars show where the ranges of duration of adjacent stages overlap. For abbreviation of developmental stages see Table 3. 
time intervals in Figure 2, certain undetermined factors either delay or accelerate growth of the animals. The external criteria of head diameter, weight and pigmentation are appropriate to allot a larva or pupa randomly taken out of a comb to a defined place on the developmental axis.

\author{
Received for publication in August 1979
}

\title{
ACKNOWLEDGEMENT
}

Wc are grateful to Gerhard ScHмid, Saulgrub, for queen rearing.

\section{ZUSAMMENFASSUNG}

\section{CHARAKTERISIERUNG DER POSTEMBRYONALEN ENTWICKLUNGSSTADIEN BEI DEN WEIBLICHEN KASTEN DER HONIGBIENE. APIS MELLIFERA L.}

Die Entstehung weiblicher Kasten bei der Honigbiene aus ursprünglich bipotenten Larven bietet neben praktischen Gesichtspunkten auch ein faszinierendes Modell zum Studium von Differenzierungs vorgängen, sowohl aus morphologischer und physiologischer, als auch aus biochemischer Sicht. Entsprechende Untersuchungen setzen jedoch eine möglichst genaue Bestimmbarkeit des Entwicklungsstadiums der Larven und Puppen voraus. In der vorliegenden Untersuchung werden einfach zu beobachtende äussere Merkmale beschrieben, die es gestatten, die Arbeiterin- und Königinlarven bzw. puppen der Honigbiene auf der Entwicklungsachse in eine definierte Position einzuordnen. Als Untersuchungsmaterial dienten Bienen der Carnica-Rasse.

Zur Charakterisierung der Larvenstadien verwandten wir die Messung des Koptkapseldurchmessers. Nach Berthol.F (1925) bleibt dieser bei der Bienenlarve innerhalb eines bestimmten Larvenstadiums nahezu gleich und nimmt mit den einzelnen Häutungen sprunghaft $z u$. Um statistisch signifikante Aussagen machen zu können, verglichen wir Kopfdurchmesser und Gewicht von 501 Arbeiterin und 464 Königinlarven. Die graphische Darstellung (Abb. 1) liefert jeweils 5 Gruppen, die den Larvenstadien der Honigbiene entsprechen. In Tabelle 1 sind die hoch signifikant voneinander verschiedenen Mittelwerte des Kopfdurchmessers $(2 p<0.001)$ sowie die dazugehörigen Gewichtsbereiche für jedes Larvenstadium angegeben (L 1-L $4=1 .-4$. Larvenstadium; L $5=5$. Larvenstadium in der offenen Zelle; LS Spinnmade im 5. Larvenstadium in der verdeckelten Zelle). Die Arbeiterinzellen wurden bei einem Larvengewicht von 150-165 mg, die Königinzellen bei etwa $190 \mathrm{mg}$ verdeckelt. Nach Beendigung des Spinnens geht die Larve in das Vorpuppenstadium (PP) über. das durch die gestreckte und unbewegliche Lage der Larve in der Zelle gekennzeichnet ist. Gleichzeitig wird die zunchmende Ablösung der larvalen Kutikula von der darunter liegenden Puppenkutikula sichtbar.

Die anschliessende Puppenentwicklung wurde an Königinnen und Arbeiterinnen verfolgt, deren Zellen nach dem Verdeckeln oder nach der Verpuppung an der Spitze etwas geöffnet und mit einem Deckglas wieder verschlossen wurden. Die Puppen wurden im Brutschrank gehalten und alle 6 Stunden auf die Pigmentierung der Komplexaugen und des Thorax untersucht (Tab. 2). Dic Augenpigmenticrung wurde mit Hilfe der Farbtabelle Ral-F2 (RA1, 1976) beschrieben. Gleichzeitig wurde die Daluer der Puppenentwicklung registriert.

Die Dauer der einzelnen Larvenstadien wurde mit Larven bestimmt, die innerhalb von 4 Stunden geschlüpft and zu verschiedenen Zeitpunkten in einem 4-bis 6-Stundenrhythmus gesammelt waren. Da bei den Larven und Puppen eine gewisse Streuung in der Entwicklungsgeschwindigkeit festgesteltt wurde, sind für die Larvenstadien jeweils eine minimale und eine maximale Dauer und für die Puppen Zeitintervalle, 
die jeweils $75 \%$ der Beobachtungen beinhalten. angegeben (Tab. 3). Abbildung 2 gibt eine Übersicht über die Gesamtentwicklung und das Alter, zu dem die einzelnen Entwicklungsphasen zu erwarten sind. Die senkrechten Balken deuten die sich überschneidenden Zeitintervalle an.

\section{RÉSUMÉ}

\section{CARACTÉRISATION DES STADES DE DÉVELOPPEMENT POST EMBRYONNAIRI: DES CASTES FEMELLES CHLZ LABEILLE, APIS MIIILIIIIR. $1 \mathrm{~L}$.}

Le développement des castes femelles de l'Abeille à partir de larves bipotentielles représente, à côté des aspects pratiques impliqués, un modèle intéressant $\mathrm{cn}$ vue d'une étude morphologique, physiologique ou biochimique des processus de différentiation. Toutefois, les analyses de ce genre présupposent la determination la plus exacte possible du stade de développement dans lequel se trouvent les larves et les nymphes examinées. Les auteurs de la présente étude décrivent des caractéristiques extéricures simples à observer, permettant d'assigner une position définie sur laxe du développement à des larves et des nymphes d'ouvrière ou de reine. L'étude a été effectuée avec des abeilles de la race carnic'a.

Les différents stades larvaires ont été caractérisés à l'aide de la mesure du diamètre de la tête. D’après BERTHOLF (1925), le diamètre en question demeure presque inchangé chez les larves d'Abeille durant un stade larvaire défini et il augmente fortement avec chaque mue. Afin d'obtenir des données statistiquement significatives, les auteurs ont comparé le diamètre de la tête avec le poids de 501 larves d'ouvrières et de 464 larves royales. La représentation graphique fait apparaitre 5 groupes correspondant aux stades larvai res de l'Abeille (figure 1). Le tableau 1 indique les valeurs moyennes du diametre de la tête pour chaque stade; les différences entre les stades consécutifs sont hautement significatives $(2 p<0.001)$. En outre, le tableau donne les poids larvaires minima et maxima correspondants ( $\mathrm{L}$ - $-\mathrm{L} 4 \mathrm{H}=\mathrm{I}^{\mathrm{er}}-4^{\mathrm{c}}$ stade larvaire; L $5:-5^{\mathrm{e}}$ stade larvaire dans la cellule non operculée; LS $=5^{\mathrm{e}}$ stade larvairc dans la cellule operculée lors du filage du cocon). Les cellules d’ouvrière ont été operculées avec un poids larvaire de 150 à $165 \mathrm{mg}$, les cellules royales avec $190 \mathrm{mg}$ environ. Le cocon étant filé, les larves entrent dans le stade prenymphal (PP) qui se caractérise par la position allongée et immobile des larves dans leur cellule. Pendant ce temps l'on peut observer le détachement progressif de la cuticule larvaire de celle de la nymphe.

Le développement nymphal a été observé avec des reines et des ouvrières dont les cellules ont été ouvertes à la pointe après l'operculation ou la pupation, et refermées à l'aide d'un couvre-objet en verre. Les cellules furent maintenues dans un incubateur, le degré de la pigmentation des yeux et du thorax des nymphes a été examiné toutes les 6 heures (tableau 2). La pigmentation des yeux a été décrite au moyen du tableau de couleurs RAL-F 2 (RAL, 1976). La même expérience a servi à la mesure de la durée du développement nymphal.

La durée des différents stades larvaires a été déterminée à l'aide de larves écloses dans une période de 4 heures et prélevées à des âges différents avec un rythme de 4 à 6 heures. Étant donné une certaine variation dans la vitesse du développement observée tant chez les larves que chez les nymphes, le tableau 3 indique pour les stades larvaires une durée minimum et maximum, et pour les nymphes un intervalle de temps comprenant chaque fois $75 \%$ des observations faites. La figure 2 montre un aperçu du développe ment post-embryonnaire et de l'âge avec lequel les différents stades de ce développement peuvent être attendus. Les barres verticales indiquent les intervalles de temps respectifs ainsi que leur recoupement.

\section{REFERENCES}

Bertholf L. M., 1925. - The moults of the honeybee. J. Econ. Ent., 18, 380-384.

Czoppelt C. and Rembold H., 1970. - Vergleichende Analyse des Kohlenhydratstoffwechsels bei den Kasten der Honigbiene, Apis mellifera. J. Ins. Physiol., 16, 1249-1264.

Dyar H. G., 1890. - The number of moults of Lepidopterous larvae. Psyche, 5, 420-422. 
JAY S. C., 1962. - Colour changes in honeybee pupae. Bee World, 43, 119-122.

JAY S. C., 1963. - The development of honeybees in their cells. J. Apic. Res., 2, 117-134.

JeNKIN P. M. and Hinton H. E., 1966. - Apolysis in arthropod moulting cycles. Nature, $211,871$.

Koehler A., 1923. - Über die postembryonale Entwicklung der Honigbiene. Landw. Jahrb. Schweiz, 37, 183-192.

Melampy R. M. and WILlis E. R., 1939. - Respiratory metabolism during larval and pupal development of the female honeybee (Apis mellifica L.). Physiol. Zool., 12, 302-311.

Milum V. G., 1930. - Variations in time of development of the honcy bee. J. Econ. Ent., 23, 441-447.

MYSER W. C., 1954. - The larval and pupal development of the honey bee Apis mellifera Linnaeus. Annals Ent. Soc. Am., 47, 683-711.

Osanal M. and Rembold H., 1968. - Entwicklungssabhängige mitochondriale Enzymaktivitäten bei den Kasten der Honigbiene. Biochim. Biophy's. Acta, 162, 22-31.

OsanaI M. and Rembold H., 1970. - Biosynthese von Cytochrom c, I. In-vivo Einbau von radioaktivem Eisen $\left({ }^{59} \mathrm{Fe}^{2+}\right)$ und $\left[{ }^{14} \mathrm{C}\right]$ Lysin in das Cytochrom c der Honigbienc. Hoppe Scyler's Z. Physiol. Chein., 351, 643-648.

RaL, 1976. - Übersichtskarte RAL-F 2 zum Farbregister RAL 840 HR. (RAL, Ausschuss für Lieferbedingungen und Gütesicherung, ed.) Muster-Schmidt KG, Göttingen.

Rembold H. and Hanser G., 1964. - Über den Weiselfuttersaft der Honigbiene, VIII. Nachweis des determinierenden Prinzips im Futtersaft der Königinnenlarven. Hoppe-Seyler's Z. Physiol. Chem., 339, $251-254$.

RHEIN W. von, 1933. - Über die Entstehung des weiblichen Dimorphismus im Bienenstaate. Roux' Arch. Entw. mech. Organ., 129, 601-665.

STABE H. A., 1930. - The rate of growth of worker, drone and queen larvae of the honeybee, A pis mellifera L. J. Econ. Ent., 23, 447-453.

Straus J., 1911. - Die chemische Zusammensetzung der Arbeitsbienen und Drohnen während ihrer verschiedenen Entwicklungsstadien. Z. Biol., 56, 347-397.

ThOMPSON P. R., 1978. - Histological development of cuticle in the worker honeybec, Apis mellifera Adansonii. J. Apic. Res., 17, 32-40.

WANG D. I., 1965. - Growth rates of young queen and worker honeybee larvae. J. Apic. Res., 4, 3-5.

WEAVER N., 1957. - Effects of larval age on dimorphic differentiation of the female honey bee. Annals Ent. Soc. Am., 50, 283-294.

WEAver N., 1974. - Control of dimorphism in the female honeybee 2. Methods of rearing larvae in the laboratory and of preserving royal jelly. J, Apic. Res., 13, 3-14.

WEISs K., 1971. - Über Ausbildung und Leistung von Königinnen aus Eiern und jungen Arbeitermaden. Apidologie, 2, 3-47.

ZANDER E. and BecKer F., 1925. - Die Ausbildung des Geschlechtes bei der Honigbiene II. Erlanger Jahrb. Bienenk., 161-246.

Zander E., Löschel F. and Meıer K., 1916. - Die Ausbildung des Geschlechtes bei der Honigbiene (Apis mellifica L.). Z. angew. Ent., 3, 1-74. 